\title{
ПОЛУЧЕНИЕ СУЛЬФИДОВ ЖЕЛЕЗА ПРИ КРИСТАЛЛИЗАЦИИ ИЗ ГАЛОГЕНИДНЫХ РАСПЛАВОВ ПОД КОНТРОЛИРУЕМЫМ ДАВЛЕНИЕМ ПАРОВ СЕРЫ
}

\author{
(C) 2017 С. С. Березин ${ }^{1}$, А. Ю. Завражнов ${ }^{1}$, А. В. Наумов ${ }^{1}$, В. В. Волков ${ }^{2}$, \\ А. В. Сергеева ${ }^{3}$, А. П. Спесивцева ${ }^{1}$ \\ 'Воронежский государственный университет, Университетская пл., 1, 394018 Воронеж, Россия \\ ${ }^{2}$ Институт общей и неорганической химии РАН им. Н. С. Курнакова, \\ Ленинский проспект, 31, 119991 Москва, Россия \\ ${ }^{3}$ Институт вулканологии и сейсмологии ДВО РАН, \\ бульв. Пийпа, 9, 983006 Петропавловск-Камчатский, Россия \\ e-mail:alzavr08@rambler.ru \\ Поступила в редакцию 28.12.2016 г.
}

\begin{abstract}
Аннотация. Разработан и применен способ управляемого синтеза однофазных монокристаллических образцов сульфидов железа с заданным фазовым и нестехиометрическим составом. Способ основан на перекристаллизации сульфидов железа из расплавов дигалогенидов железа $\left(\mathrm{FeHal}_{2}, \mathrm{Hal}=\mathrm{Cl}, \mathrm{Br}, \mathrm{I}\right)$ при контролируемом давлении паров серы. Перекристаллизация сульфидов железа проводилась в закрытой системе в двухтемпературном варианте, при котором давление паров серы задавалось постоянной температурой холодной зоны, а температура горячей зоны с расплавом медленно снижалась. При использовании в качестве растворителя хлоридных и бромидных расплавов были выделены кристаллы пирита $\beta-F e S$, при давлении паров серы от 0.42 до 9.4 атм. Параметр а кубической решетки пирита оказался равным 0.5412-0.5413 нм. При давлении, меньшем 0.25 атм, кристаллизовалась смесь пирита с тригональной фазой $\mathrm{Fe}_{1-x} \mathrm{~S}$. При использовании в качестве растворителя иодида железа (II) проходила реакция, в которой элементарная сера окисляла иодид-ион, что также приводило к образованию сульфидов железа. Предложен механизм кристаллизации сульфидов железа.
\end{abstract}

Ключевые слова: кристаллизация из расплава, галогениды металлов, сульфиды железа, пирит, пирротин, двухтемпературный синтез.

\section{ВВЕДЕНИЕ}

Промежуточные фазы системы Fe-S являются потенциально перспективными материалами в разных областях наукоемких сфер. Несмотря на то что фазы, близкие по стехиометрии к составу FeS ( $\gamma$-пирротин, $\alpha$-пирротин, троилит), малопривлекательны для материаловедения, их чувствительные к нестехиометрии свойства (оптические и магнитные) могут быть использованы в качестве маркеров при обнаружении в рудах ценных сопутствующих минералов [1,2]. Большие надежды на практическое использование связаны с дисульфидом железа $\mathrm{FeS}_{2}$ в фазе пирита, который рассматривается как перспективный материал для солнечной энергетики $\left(E_{g}=0.95\right.$ эВ, поглощение в ближней ИК области) [3-6]. В работах [5-6] отмечается, что возможности оптимизации свойств пирита, открывающиеся при регулировании его состава в пределах области гомо- генности, далеко не исчерпаны. Вместе с тем даже сама фазовая диаграмма системы $\mathrm{Fe}-\mathrm{S}$ в области умеренных и низких температур (<650-680 $\left.{ }^{\circ} \mathrm{C}\right)$ является дискуссионной [7-9]. Не выяснено до сих пор, являются ли марказит, а также «гибридные» между пиритом и марказитом структуры $\mathrm{FeS}_{2}$ (типа парараммельсбербита [10]) всегда, то есть при любых $T, p, x$, метастабильными относительно пирита. Не ясен вопрос также о количестве и структурах фаз, присутствующих при относительно низких температурах в окрестности соединения $\mathrm{FeS}$, при $0.46 \leq x_{\mathrm{s}} \leq 0.56$ (рис. 1 ).

Причина указанных сложностей связана, прежде всего, с трудностью достижения равновесных состояний, а также с легкостью образования метастабильных состояний для данной системы при относительно невысоких температурах. По этой причине многие исследователи отдают предпочте- 


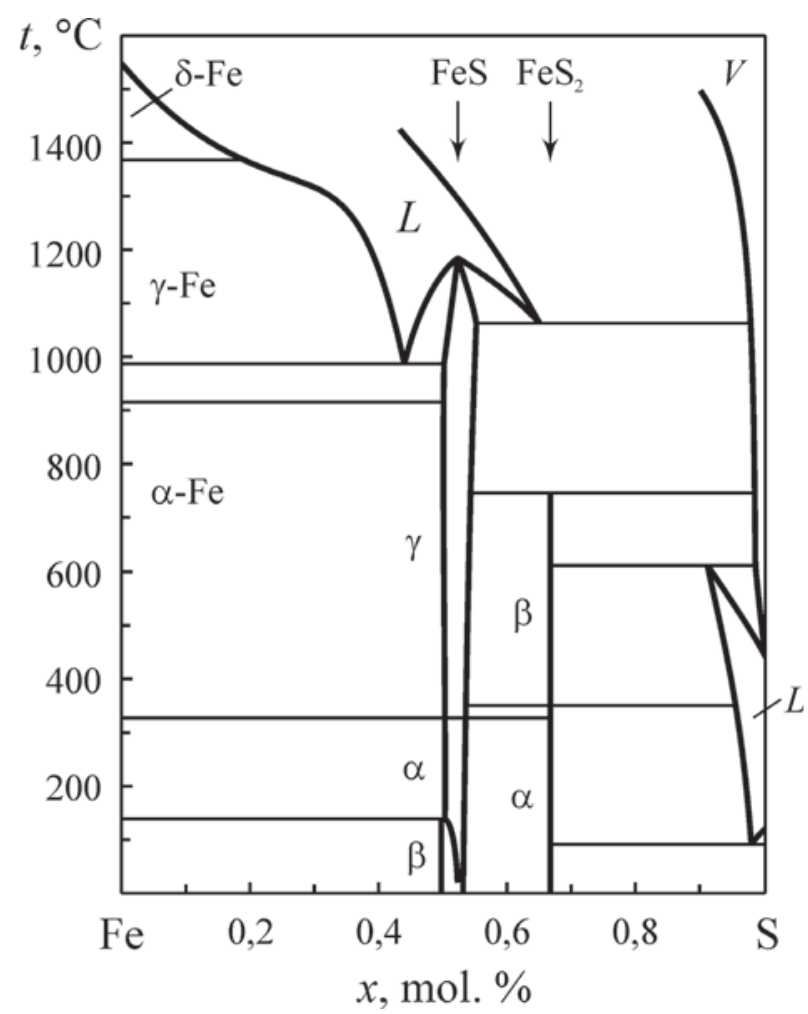

Рис. 1. Фазовая диаграмма системы Fe-S по [9]

[Fig. 1. Phase diagram of the Fe-S system (according to ref. [9])]

ние минералогическим находкам сульфидов железа, для которых времена релаксации в природных условиях могут на много порядков превосходить времена отжига в лабораторных экспериментах [11-12]. Однако и такой подход не гарантирует получение достоверной информации по фазовой диаграмме, поскольку не известны с достаточной точностью давления и температуры, при которых находился образец, не контролируется вхождение примесей.

С учетом изложенного, цель настоящей работы состояла в изучении фазовых отношений в системе $\mathrm{Fe}-\mathrm{S}$ в области умеренных температур (330-680 $\left.{ }^{\circ} \mathrm{C}\right)$. Первоочередная задача, решение которой было необходимо для достижения этой цели, состояла в отыскании способа управляемого синтеза однонофазных монокристаллических образцов сульфидов железа с заданным нестехиометрическим составом.

\section{МЕТОДИКА ЭКСПЕРИМЕНТА}

\section{Кристаллизация из галогенидных расплавов.}

Для решения этой задачи нами применен способ синтеза монокристаллов сульфидов железа, основанный на перекристаллизации из расплавов дигалогенидов железа $\left(\mathrm{FeHal}_{2}, \mathrm{Hal}=\mathrm{Cl}, \mathrm{Br}, \mathrm{I}\right)$ при контролируемом давлении паров серы. Кроме чистых дигалогенидов железа в качестве растворителей также использовались эвтектические расплавы систем $\mathrm{KCl}-\mathrm{FeCl}_{2}$ и $\mathrm{NaCl}-\mathrm{KCl}-\mathrm{FeCl}_{2}$. Такой способ был выбран с учетом того, что сульфиды железа обладают заметной растворимостью в расплавах $\mathrm{FeCl}_{2}, \mathrm{FeBr}_{2}[13,14]$. Низкие скорости кристаллизации сульфидов железа позволяли, по нашему предположению, приблизится в условиях невысоких температур к состояниям, близким к равновесным. Нижняя граница выбранного в работе температурного интервала $\left(330{ }^{\circ} \mathrm{C}\right)$ соответствовала кристаллизации эвтектического расплав $\mathrm{NaCl}-\mathrm{KCl}-\mathrm{FeCl}_{2}$, верхняя $\left(690^{\circ} \mathrm{C}\right)$ - температуре выделения сульфидов железа из расплава $\mathrm{FeBr}_{2}$ (дибромид железа - наиболее тугоплавкое из выбранных дигалогенидов соединение).

Перекристаллизацию сульфидов железа проводили в закрытой системе в двухтемпературном варианте согласно следующей схеме. Реактор для синтеза представлял собой цилиндрическую кварцевую ампулу с внутренним диаметром 16 - 18 мм и длиной $300-400$ мм с небольшим уменьшением диаметра у одного из концов ампулы. Один конец конструкции оставался запаянным, а к противоположному концу приваривали тонкую кварцевую трубку для вакуумирования и отпайки. В один конец реактора помещали элементарную серу (5-10 г), а в другой - заранее синтезированную порошкообразную смесь $\mathrm{Fe}_{1-x} \mathrm{~S}$ и $\mathrm{FeS}_{2}(\sim 0.3-0.5$ г) и безводный дигалогенид железа (4-7 г). После вакуумирования и отпайки реактор помещали в горизонтальную двухзонную печь, конструкция которой позволяла вести визуальное наблюдение за образцом. Концу ампулы со смесью сульфидов и галогенида железа соответствовала более высокая температура $T_{2}$, а противоположному концу с серой - более низкая $T_{1}$. Величиной $T_{1}$ определялось давление насыщенного пара серы. Поскольку все фазы системы $\mathrm{Fe}-\mathrm{S}$ характеризуются инконгруэнтной сублимацией - такой при которой в пар переходят практически только молекулярные формы серы - суммарное давление $p_{\mathrm{s}}$ должно определять как фазовую принадлежность, так и состав выращиваемых кристаллов сульфидов железа.

Давление паров серы задавали в пределах от 0.25 до 9.5 атм (температуры $T_{1}$ - от 360 до $640{ }^{\circ} \mathrm{C}$ ). Изменяя температуру $T_{2}$, регулировали насыщение расплава сульфидами железа и последующую их кристаллизацию. При температуре, на $15-20{ }^{\circ} \mathrm{C}$ превосходящей температуру плавления дигалогенида, образец выдерживали в течение 20 часов для 
насыщения расплава галогенида сульфидом. Далее постепенно, в течение нескольких часов, температуру $T_{2}$ снижали до величины, на $10-15{ }^{\circ} \mathrm{C}$ ниже температуры плавления дигалогенида железа. Давление паров серы оставалось фиксированным. После кристаллизации всего расплава систему охлаждали в режиме выключенной печи. Скорость охлаждения горячей зоны составляла около 10 К/мин.

Для выделения закристаллизованных сульфидов железа полученную гетерогенную смесь, содержащую галогениды и сульфиды, обрабатывали дистиллированной водой, вымывая хорошо растворимые галогениды. Осадок промывали последовательно этанолом и толуолом, а затем высушивали. В процессе многократных промываний очень мелкий порошок исходных сульфидов железа практически полностью отделялся от хорошо закристаллизованного материала.

Отжиговые эксперименты. Для выяснения вопроса о стабильности марказита относительно пирита порошок смеси пирита и марказита отжигали под слоем расплава эвтектической смеси $\mathrm{KCl}-\mathrm{FeCl}_{2}$ (38 мол. \% $\left.\mathrm{FeCl}_{2}, t_{\text {эвт }} \approx 350^{\circ} \mathrm{C},[15]\right)$ или $\mathrm{NaCl}-\mathrm{KCl}-\mathrm{FeCl}_{2}$ (12 мол. \% $\mathrm{NaCl}, 48$ мол. \% $\mathrm{FeCl}_{2}$, $\left.t_{\text {эвт }}=305 \pm 2{ }^{\circ} \mathrm{C}[16]\right)$. Поскольку воспроизводимый синтез марказита $\left(\alpha-\mathrm{FeS}_{2}\right)$ сложен, в наших экспериментах в качестве исходного образца брали природную смесь пирита и марказита Нижне-Кошелевского гидротермального месторождения (п-ов Камчатка). Количество хлоридной смеси было таким, что в условиях эксперимента расплав полностью покрывал порошок $\mathrm{FeS}_{2}$, хорошо смачивающийся расплавленными хлоридами. После вакуумирования и отпайки ампулу с веществами размешали на изотермическом участке печи с температурой $360{ }^{\circ} \mathrm{C}$. Далее проводили отжиг, завершающийся охлаждением в режиме выключенной печи. Сульфиды железа после отжига отделяли от хлоридов по описанной выше схеме.

Рентгенофазовый анализ и электронная микроскопия. Полученные образцы идентифицировали методом рентгенофазового анализа (РФА). Дифрактограммы записывали на порошковом дифрактометре Shimadzu XRD-7000 с использованием монохроматизированного $\mathrm{Cu} K_{\alpha 1}$-излучения. Съемку вели с шагом отсчетов $0.05^{\circ}$ по $2 \theta$ при времени экспозиции 6.0 с в точке. Модельные дифрактограммы для известных структур рассчитывали по литературным данным для условий эксперимента (программа PowderCell 2.4).

Полученные образцы были исследованы также при помощи сканирующей электронной микроско- пии (CЭМ) на приборе JEOL JSM-7001F. Для ряда монокристаллов на рентгенофлуоресцентном анализаторе S8-Tiger было выполнено количественное определение элементного состава.

\section{РЕЗУЛЬТАТЫ И ОБСУЖДЕНИЕ}

Фазовый состав и фазовые превращения. Как показали рентгеновские исследования, кристаллы, выращенные из расплавов $\mathrm{FeCl}_{2}$ и $\mathrm{FeBr}_{2}$ при давлении паров серы выше 0.42 атм, представляют собой единственную фазу пирита $\beta-\mathrm{FeS}_{2}$ и характеризуются в основном комбинированным габитусом куба и пентагондодекаэдра (рис. $2 a$ ). На некоторых гранях видны ступени роста (рис. $2 b$ ). Наиболее ровные грани формируются при давлениях паров серы до 2 атм, а при бульших давлениях на некоторых гранях проявляются характерные фигуры роста, связанные, по-видимому, с выходами дислокаций (рис. $2 c$ ). Предельное значение давления паров серы, выше которого при температуре $\sim 680{ }^{\circ} \mathrm{C}$ кристаллизуется единственная фаза пирита, коррелирует с данными работы [6], в которой была определена температурная зависимость суммарного давления пара серы в равновесии $\gamma-\mathrm{Fe}_{1-x} \mathrm{~S}-\beta-\mathrm{FeS}_{2}-V$.

Параметр кубической решетки пирита (пр. гр. $P a \overline{3})$ проявляет очень слабую чувствительность к давлению паров серы при синтезе. Максимальное зна-

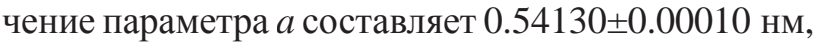
минимальное $-0.54116 \pm 0.00001$ нм.

Образцы пирита, полученные из расплавов иодида железа (II), кристаллизовались при температуре, на $80{ }^{\circ} \mathrm{C}$ меньшей по сравнению с выращенными из хлоридных и бромидных расплавов. Они характеризуются наименьшими значениями параметра решетки - до $0.54114 \pm 0.00002$ нм. В целом параметры решетки пирита оказываются несколько меньшими, чем обычно указывается в литературе (например, 0.547 нм [10]).

Отжиг пирит-марказитной смеси с эвтектическими расплавом $\mathrm{KCl}-\mathrm{FeCl}_{2}$ вели при температурах $365,400,450$ и $500{ }^{\circ} \mathrm{C}$ в течение 36 часов. Отжиг при самой высокой температуре приводил к полной трансформации марказита в пирит, при самой низкой $\left(365^{\circ} \mathrm{C}\right)$ оставлял образец практически без изменений; при двух промежуточных температурах обнаруживалось явное уменьшение доли марказита в образце (рис. 3). Оценочные объемные доли марказита в отожженных образцах приведены в табл.

Для выявления вопроса о трансформации $\alpha-\mathrm{FeS}_{2} \rightarrow \beta-\mathrm{FeS}_{2}$ при низких температурах, нами 


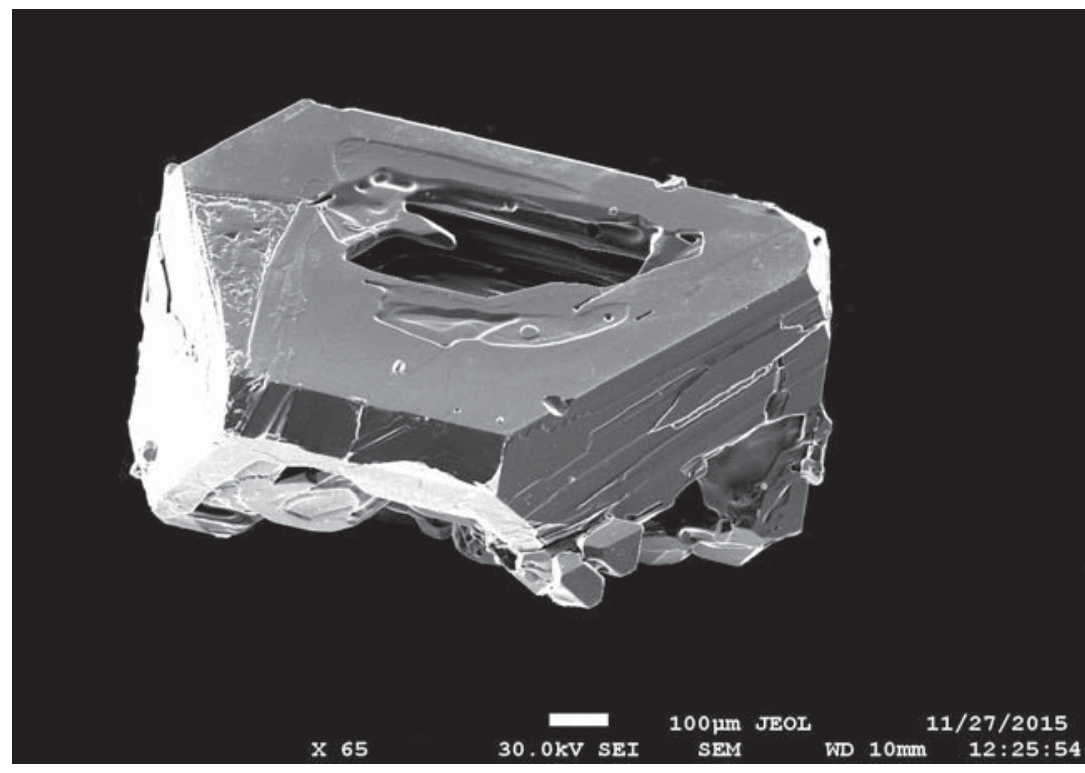

$a$

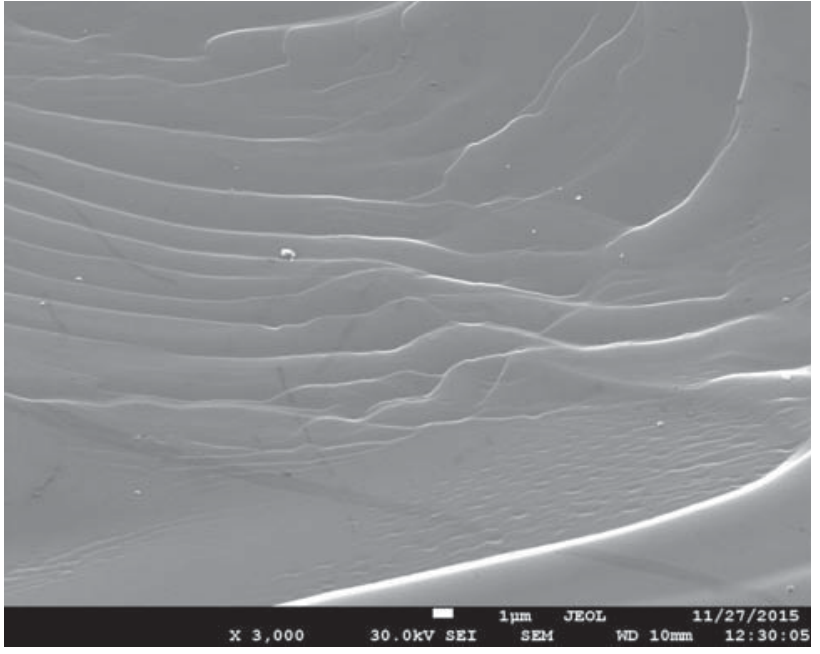

$b$

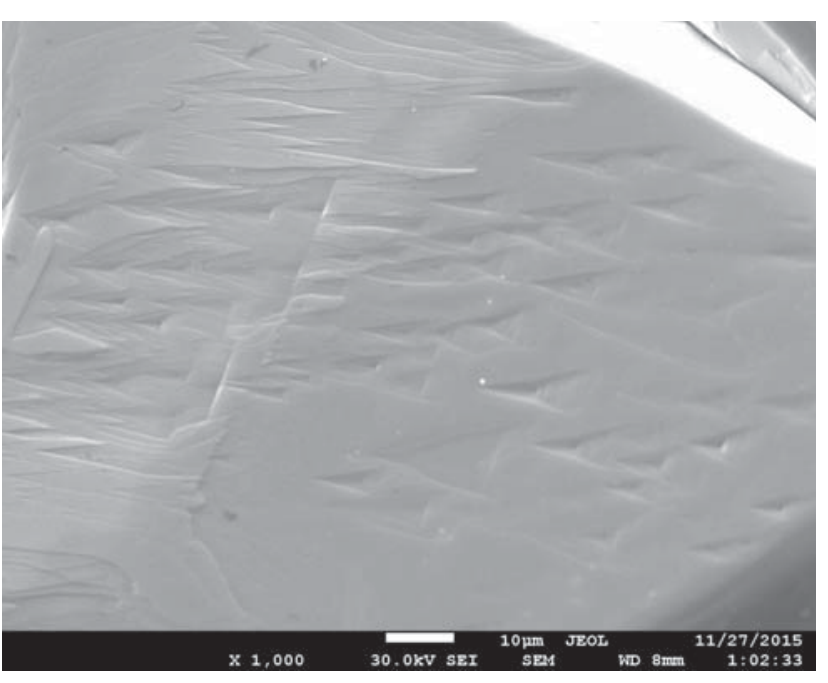

$c$

Рис. 2. Изображения поверхности монокристаллов пирита, полученных перекристаллизацией сульфида железа из расплава $\mathrm{FeBr}_{2}$ при давлениях паров серы 1 атм $(a, b)$ и 10 атм $(c)$

[Fig. 2. Surface images for the pyrite single crystals, grown by the iron sulfide recrystallization from $\mathrm{FeBr}_{2}$ melts in a contact with sulfur vapor: 1 bar $(a, b)$ and 10 bar $(c)$ ]

Таблица. Объемные доли пирита в пирит-марказитовых смесях, отожженных с эвтектическими расплавом $\mathrm{KCl}-\mathrm{FeCl}_{2}$ в течение 36 часов

[Table. Pyrite-phase volume fractions in the pyrite-marcasite mixtures after the $36 \mathrm{~h}$ - annealing of the native pyritemarcasite samples under the $\mathrm{KCl}-\mathrm{FeCl}_{2}$ eutectic melt]

\begin{tabular}{|c|c|}
\hline $\begin{array}{c}t_{\text {отжига }},{ }^{\circ} \mathrm{C} \\
{\left[t_{\text {annealing, }},{ }^{\circ} \mathrm{C}\right]}\end{array}$ & $\begin{array}{c}\text { Об. доля пирита, \% } \\
\text { [Pyrite volume fraction, \% }]\end{array}$ \\
\hline $\begin{array}{c}\text { исх. образец } \\
\text { [initial sample }]\end{array}$ & 47.2 \\
\hline 365 & 46.8 \\
\hline 400 & 68.6 \\
\hline 450 & 80.7 \\
\hline 500 & 100.0 \\
\hline
\end{tabular}

был проведен аналогичный эксперимент при $360{ }^{\circ} \mathrm{C}$ с использованием более легкоплавкой эвтектики $\mathrm{NaCl}-\mathrm{KCl}-\mathrm{FeCl}_{2}$ при значительно большем времени отжига (160 ч). Этот эксперимент, согласно рентгеновским данным, привел к полной трансформации марказита в пирит. Таким образом, можно считать установленной метастабильность марказита относительно пирита (по крайней мере, при $\left.T \geq 360{ }^{\circ} \mathrm{C}\right)$.

Наиболее интересные данные, на наш взгляд, были получены для образцов, выращенных из расплавов при низких давлениях паров серы 0.20 атм и менее. В этом случае из галогенидного расплава кристаллизовалась, с примесью пирита, 


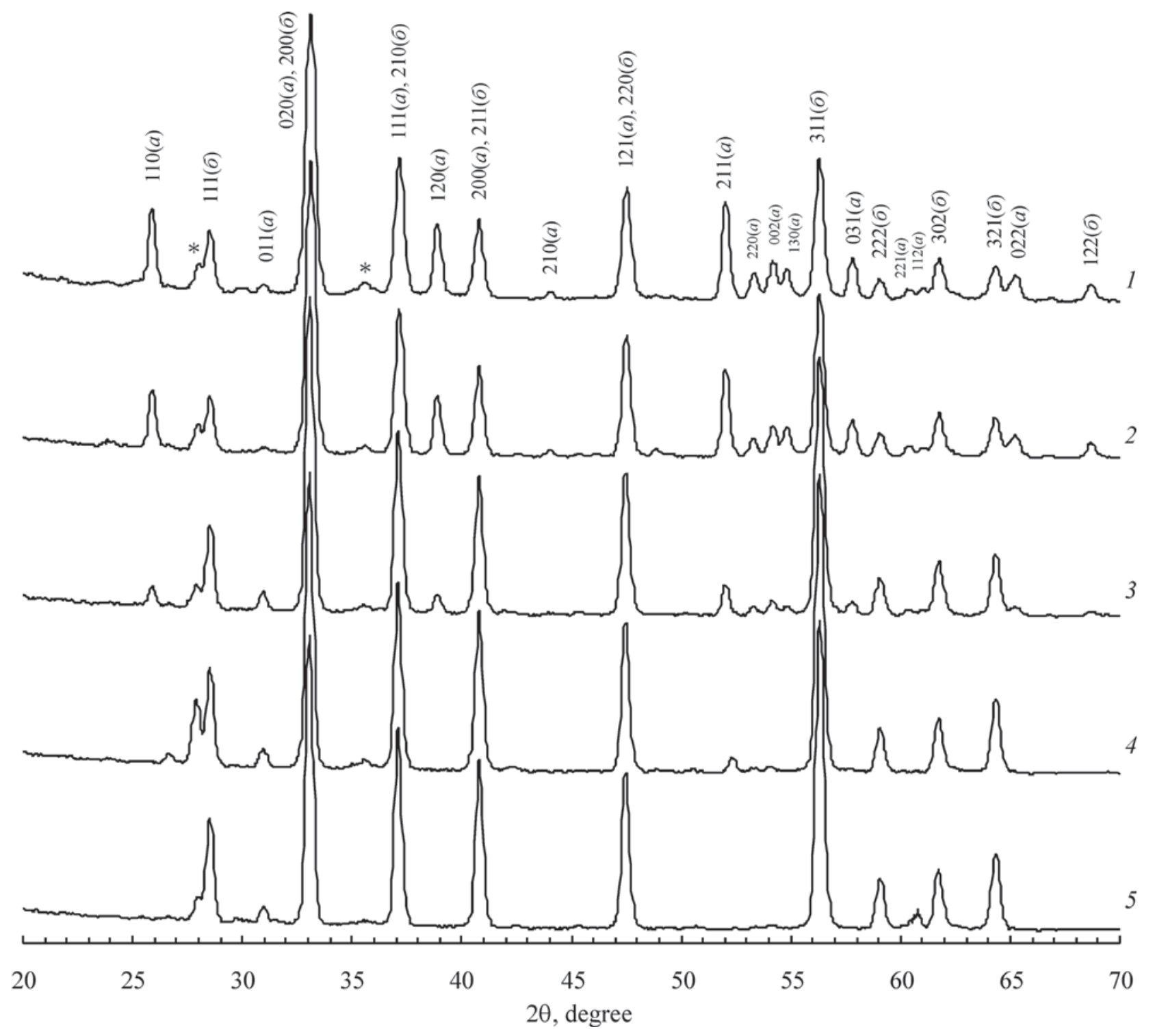

Рис. 3. Дифрактограммы пирит-марказитовых смесей ( 1 - исходный образец), отожженных с эвтектическими расплавом $\mathrm{KCl}-\mathrm{FeCl}_{2}$ в течение 36 часов при температурах: $2-365 ; 3-400 ; 4-450 ; 5-500{ }^{\circ} \mathrm{C} ; a$ - рефлексы марказита, $\alpha-\mathrm{FeS}_{2}(P n n m) ; b$ - пирита, $\beta-\mathrm{FeS}_{2}(P a \overline{3}) ;$;вездочка - силикатная примесь

[Fig. 3. Diffraction patterns (powder) of pyrite-marcasite mixtures ( 1 - initial native sample), which had 36-hours annealing under the $\mathrm{KCl}-\mathrm{FeCl}_{2}$ eutectic melts at the following temperatures: $2-365 ; 3-400 ; 4-450 ; 5-500{ }^{\circ} \mathrm{C} ; a$ - marcasite $\left(\alpha-\mathrm{FeS}_{2}\right.$, Pnnm) peaks; $b$ - pyrite $\left(\beta-\mathrm{FeS}_{2}, P a \overline{3}\right)$ peaks; * - the notation for the silicate impurity]

фаза, близкая по составу к моносульфиду железа. Результаты рентгенофазового анализа показали, что выделяется тригональная фаза (пр. гр. $P 3{ }_{1} 21$ ), кристаллическая решетка которой представляет собой упорядоченную дефектную структуру на основе $\gamma-\mathrm{Fe}_{1-x} \mathrm{~S}$ (пр. гр. $P 6_{3} / m m c$, структурный тип NiAs). Эта фаза определяется как тип пирротина-3T [17] с параметрами элементарной ячейки $a$ в диапазоне $0.68718-0.68836$ нм и $c$ в диапазоне $1.70692-1.71082$ нм.

По причинам, которые будут обсуждаться ниже, кристаллы пирротина, полученные из расплава
$\mathrm{FeI}_{2}$, формировались при уменьшающемся в процессе их роста давлении паров серы. Таким образом, эти фазы являются, скорее всего, неравновесными - как по отношению к различным участкам внутри кристаллических тел, так и по отношению к жидким и паровым фазам системы, в которой шла кристаллизация. Кристаллизация из расплавов $\mathrm{FeCl}_{2}$ и $\mathrm{FeBr}_{2}$, напротив, по-видимому, более близка к равновесным условиям. С увеличением давления паров серы параметр решетки тригонального пирротина уменьшается. Это хорошо коррелирует с известным фактом, что доминирующими 
дефектами в пирротинах являются вакансии в подрешетке железа: увеличение содержания этих вакансий с ростом давления паров серы должно приводить к уменьшению величин $a$ и $c$.

Реакционные пути кристаллизации сульфидов жселеза. Мы предполагаем, что в основе образования сульфидов железа из галогенидных расплавов в описанных условиях лежит обратимая реакция окисления серой $\left(\mathrm{S}^{0}\right)$ расплавленных галогенидов железа (II) до свободных галогенов:

$$
\frac{n}{2} \mathrm{~S}_{2}^{(V)}+2 \mathrm{Hal}^{-(L)} \rightleftarrows \mathrm{S}_{n}^{2-(L)}+\mathrm{Hal}_{2}^{(V)},
$$

где $V$ - паровая фаза; $L-$ расплав; $n=1$ или 2. Выделяющаяся в (1) восстановленная форма серы связывается железом $\left(\mathrm{Fe}^{2+}\right)$ в кристаллический сульфид железа:

$$
\mathrm{S}_{n}^{2-(L)}+\mathrm{Fe}^{2+(L)} \rightleftarrows \mathrm{FeS}_{n}^{(S)} .
$$

В случае хлоридов и бромидов выделяющийся в (1) свободный галоген может частично связываться в тригалогенид железа и галогенид серы (I):

$$
\begin{gathered}
\mathrm{FeHal}_{2}^{(L)}+\frac{1}{2} \mathrm{Hal}_{2}^{(V)} \rightleftarrows \mathrm{FeHal}_{3}^{(V)}, \\
\mathrm{S}_{2}^{(V)}+\mathrm{Hal}_{2}^{(V)} \rightleftarrows \mathrm{S}_{2} \mathrm{Hal}_{2}^{(V)} .
\end{gathered}
$$

Смещение равновесий (1) и (2) при варьировании давления и температуры может приводить к кристаллизации сульфидов железа или, наоборот, к их растворению в расплавах галогенидов $\mathrm{FeHal}_{2}$. Оценочный термодинамический расчет, выполненный при использовании данных [18] показывает, что для реакций

$$
\begin{gathered}
\mathrm{FeHal}_{2}^{(L)}+\mathrm{S}_{2}^{(V)} \rightleftarrows \mathrm{FeS}_{2}^{(S)}+\mathrm{Hal}_{2}^{(V)}, \\
\mathrm{FeHal}_{2}^{(L)}+\frac{1}{2} \mathrm{~S}_{2}^{(V)} \rightleftarrows \mathrm{FeS}^{(\mathrm{S})}+\mathrm{Hal}_{2}^{(V)}
\end{gathered}
$$

величина $\Delta H^{\circ}$ должна быть положительной. Это означает, что уменьшение температуры $T_{2}$ должно приводить к смещению этих равновесий (а также более общих равновесий (1) и (2)) вправо и к кристаллизации сульфида железа определенного состава. Очевидно также, что увеличение давления паров серы должно приводить к аналогичному результату. Тип кристаллической структуры формирующейся твердой фазы, а также ее состав должны зависеть, как от температуры расплава, так и от величины давления паров серы, задаваемого температурой холодной зоны $\left(T_{1}\right)$. Заметим, что перекристаллизация сульфидов железа может происходить и при постоянных температуре и давлении: за счет достижения оптимальных (для условий опыта) структуры и состава или же за счет увеличения структурного совершенства и размеров кристаллов твердой фазы.

Гипотеза о существенном вкладе смещения равновесия (1) в образование сульфидов железа требовала проверки, поскольку сложно представить элементарную серу в роли окислителя хлоридов и бромидов железа (II) до элементарных галогенов при сколько-нибудь заметных концентрациях последних. В ходе такой проверки предложенный механизм кристаллизации был подтвержден следующими экспериментальными результатами.

Формирование пирита из дибромида железа в контакте с парами серы. Кристаллизацию единственной фазы $\beta-\mathrm{FeS}_{2}$ наблюдали в условиях, когда давление паров серы в ампуле задавали постоянным (4 атм, что соответствует $T_{1}=450{ }^{\circ} \mathrm{C}$ ), а расплав $\mathrm{FeBr}_{2}$ после выдерживания в течение нескольких часов при $690{ }^{\circ} \mathrm{C}$ медленно охлаждали до $670{ }^{\circ} \mathrm{C}$. Данные этого эксперимента - известный объем ампулы (180 мл) и масса выделившегося пирита (0.3001 г), - позволили ориентировочно оценить величину $K_{p}^{\#}$ при средней температуре горячей зоны $680{ }^{\circ} \mathrm{C}$. Величина $K_{p}^{\#}$ связывает парциальные давления паров серы и брома в (1) и позволяет с точностью до члена, зависящего от температуры, давления и состава жидкой фазы определить значение химического потенциала серы в фазе пирита:

$$
K_{p}^{\#}=\frac{p_{\mathrm{Ha}_{2}}}{p_{\mathrm{S}_{2}}}, \quad R T \ln K_{p}^{\#}=\mu_{\mathrm{S}_{2}}^{(S)}+f\left(T, p, x^{(L)}\right)
$$

Для расчета $K_{p}^{\#}$ необходимую величину парциального давления паров брома определяли по уравнению идеального газа с учетом количества вещества $n_{\mathrm{Br}_{2}}^{(V)}=n_{\mathrm{Fes}_{2}}$ и средней между $T_{2}$ и $T_{1}$ температуры. Полученное в результате значение $K_{p}^{\#} \approx 5 \cdot 10^{-3}$ является, по-видимому, несколько завышенным, поскольку при вычислениях не учитывалась возможная растворимость брома в горячем расплаве серы, а также частичное связывание свободного брома в трибромид железа.

Практически необратимая кристаллизация сульфидов жселеза при взаимодействии паров серы с расплавами иодида железа (II). При взаимодействии расплава иодида $\mathrm{FeI}_{2}$ с парами серы всегда происходило выделение паров иода, что отмечалось по характерной окраске паров, наблюдаемой даже на фоне окрашенных паров серы. Также наблюдалось почернение изначально красно-коричневого расплава серы за счет высокой растворимости молекулярного иода в жидкой сере. Одновременно происходила кристаллизация сульфидов железа: при $T_{1} \geq 400{ }^{\circ} \mathrm{C}$ выделялась единс- 
твенная фаза пирита, а при $T_{1} \leq 300{ }^{\circ} \mathrm{C}$ формировалась смесь пирита с пирротином $\mathrm{Fe}_{1-x} \mathrm{~S}$ в тригональной $3 T$-модификации. Такая кристаллизация происходила даже при неизменных температурных режимах и приводила к полной конверсии расплава $\mathrm{FeI}_{2}$ в фазы $3 T-\mathrm{Fe}_{1-x} \mathrm{~S}$ или (и) $\beta-\mathrm{FeS}_{2}$.

К сожалению, растворение больших количеств иода в расплаве на основе серы затрудняло прогноз величин парциальных давлений паров серы, поскольку образование раствора существенно снижает эти величины. Такой прогноз еще более осложнялся тем, что концентрация растворенного в сере молекулярного иода должна сильно зависеть, помимо температуры $T_{1}$, и от количества жидкой серы, находящейся в холодной зоне в равновесии с паром. Очевидно, что это количество менялось по мере связывания серы в сульфиды железа.

Вместе с тем, необходимо отметить возможность получения качественных кристаллов пирита из расплавов $\mathrm{FeI}_{2}$ при постоянных температурах в течение всего эксперимента, что делает такой способ синтеза потенциально перспективным.

Также в пользу рассматриваемой гипотезы о механизмах кристаллизации сульфидов железа указывают результаты очень похожего эксперимента, в котором в горячую зону помещали дибромид железа $\mathrm{FeBr}_{2}$, а в холодную - гетерофазную смесь серы с твердым иодидом калия КI. В этом случае уже после первого часа контакта расплава $\mathrm{FeBr}_{2}$ $\left(690{ }^{\circ} \mathrm{C}\right)$ с парами серы $\left(T_{1}=360{ }^{\circ} \mathrm{C}, p_{\mathrm{s}}=0.25\right.$ атм $)$ наблюдалась кристаллизация пирита из расплава, а в паровой фазе фиксировалось появление паров иода. В течение суток расплав $\mathrm{FeBr}_{2}$ полностью превращался в кристаллический пирит. Важно отметить, что в холостом опыте с нагреванием иодида калия и серы в изначально вакуумированной запаянной ампуле не наблюдалось никаких признаков выделения иода.

Описанные наблюдения объясняются поглощением паров молекулярного брома и трибромида железа в паровой фазе при их восстановлении иодидом калия по очевидным реакциям:

$$
\begin{aligned}
\frac{1}{2} \mathrm{Br}_{2}^{(V)}+\mathrm{KI}^{(S)} & \rightleftarrows \frac{1}{2} \mathrm{I}_{2}^{(V)}+\mathrm{KBr}^{(S)}, \\
\mathrm{FeBr}_{3}^{(V)}+\mathrm{KI}^{(S)} & \rightleftarrows \mathrm{K}\left[\mathrm{FeBr}_{3}\right]^{(S)}+\frac{1}{2} \mathrm{I}_{2}^{(V)}, \\
\mathrm{I}_{2}^{(V)} & \rightleftarrows \mathrm{I}_{2}^{\left(L_{S}\right)},
\end{aligned}
$$

где $L_{\mathrm{S}}$ - расплав серы. Удаление брома из паровой фазы вызывает прохождение реакций (1) и (2) в прямом направлении вплоть до полного израсходования расплава $\mathrm{FeBr}_{2}$.
Окислительные свойства твердого конденсата серы после перекристаллизации из бромидных и хлоридных расплавов. По завершении экспериментов по перекристаллизации сульфидов железа из расплавов $\mathrm{FeBr}_{2}$ и $\mathrm{FeCl}_{2}$, находящуюся в системе избыточную серу конденсировали в свободном конце реактора. После полного охлаждения реактор вскрывали. Извлеченную серу растирали в порошок в фарфоровой ступке и обрабатывали концентрированным водным раствором свежеприготовленного хлорида железа (II) с добавкой роданида калия. После такой обработки раствор приобретал красно-бордовую окраску, которая свидетельствовала об окислении гидратированных ионов $\mathrm{Fe}^{2+}$ до $\mathrm{Fe}^{3+}$. Отметим, что чистая проплавленная и затем измельченная сера не изменяла цвет роданидного раствора железа (II).

Выраженные окислительные свойства конденсат серы мог приобретать за счет образования хорошо растворимых в жидкой сере галогенидов $\mathrm{S}_{2} \mathrm{Cl}_{2}$ или $\mathrm{S}_{2} \mathrm{Br}_{2}$. Эти соединения способны окислять ионы $\mathrm{Fe}^{2+}$ до обнаруживаемых роданидом ионов $\mathrm{Fe}^{3+}$. Кроме того, вместе с конденсатом на основе серы в холодной зоне могли скапливаться также тригалогениды железа, которые непосредственно обнаруживались в реакции с роданид-ионом.

Было также обнаружено, что если конденсат серы был получен в опытах с применением расплавов хлорида железа (II), то при тестировании порошка этого конденсата совместным раствором KSCN и $\mathrm{FeCl}_{2}$ появлялось лишь весьма слабое окрашивание. Если же сера извлекалась из реактора, в котором использовался бромид железа (II), то при аналогичном тестировании возникала очень интенсивная окраска. Эти наблюдения свидетельствуют о большем смещении равновесия (1) вправо для брома по сравнению с таким же равновесием для хлора.

Таким образом, можно считать доказанным положение о существенном вкладе равновесия (1) в механизм формирования сульфидов железа по рассмотренной в работе методике.

\section{ВЫВОДЫ}

1. Разработана и успешно применена новая методика синтеза монокристаллических образцов сульфидов железа с заданной структурой и составом, основанная на взаимодействии в закрытой неизотермической системе расплавов галогенидов железа с парами серы при варьируемых величинах давлений этих паров.

2. Установлено, что фазовый состав кристаллизующегося сульфида железа зависит от давления 
паров серы: при относительно низком давлении паров серы (<0,5 атм) образуется пирротин с тригональной $3 T$-структурой, при высоким давлении - пирит $\beta-\mathrm{FeS}_{2}$.

3. Предложен и обоснован механизм перекристаллизации сульфидов железа, основанный на обратимом окислении серой дигалогенида железа.

\section{ПРИЛОЖЕНИЕ}

\section{Методика синтеза галогенидов железа (II) и эвтектических сплавов с галогенидами щелочных металлов}

Кристаллические хлорид и бромид железа (II) получали в проточной системе - открытой с двух концов цилиндрической кварцевой ампуле, последовательно пропуская над находящимся в ней разогретым до 800-900 ${ }^{\circ} \mathrm{C}$ порошком карбонильного железа (ОСЧ 6-2) потоки водорода и, далее, газообразного галогеноводорода. Предварительное пропускание водорода требовалось для восстановления окисленного с поверхности порошка железа. Галогеноводороды получали, действуя концентрированной серной кислотой на $\mathrm{NaCl}$ и $\mathrm{NaBr}$. В случае бромида натрия выделяющийся газ, содержащий, наряду с $\mathrm{HBr}$, молекулярный бром и сернистый газ, пропускали через охлаждаемую в криотермостате до $-30{ }^{\circ} \mathrm{C}$ U-образную трубку, заполненную активированным углем. Таким способом вымораживались две последние примеси.

Хлорид и бромид железа (II) получались в виде светло-коричневых поликристаллических слитков. Этот продукт далее перегоняли в токе соответствующего газообразного галогеноводорода для очистки от примесей в той же системе. Конденсат собирался в дальнем конце ампулы в форме светло-коричневого крупнозернистого порошка, состоящего из отдельных чешуек. Чистота галогенидов железа контролировалась по температурам плавления, которые определяли при использовании дифференциально-термического анализа (ДТА) по методике [19]. Найдено, что температура плавления $\mathrm{FeCl}_{2}$ составляла $674 \pm 2$, а $\mathrm{FeBr}_{2}-681 \pm 2{ }^{\circ} \mathrm{C}(677$ и $684{ }^{\circ} \mathrm{C}$ по данным [18]). Температура плавления наиболее легкоплавкого состава в системе $\mathrm{KCl}-\mathrm{FeCl}_{2}$, по данным наших термографических экспериментов, оказалась равной $350 \pm 2{ }^{\circ} \mathrm{C}$.
Работа выполнена при поддержке РФФИ, проект № 15-52-61017 Ezunem a.

\section{СПИСОК ЛИТЕРАТУРЫ}

1. Developments in Economic Geology, 30 Precambrian Ore Deposits of the East European and Siberian Cratons / Ed. by D. V. Rundquist, C. Gillen. Elsevier, 1997, $457 \mathrm{p}$.

2. Wozniakiewicz P. J., Ishii H. A. // Meteoritics \& Planetary Science, 2011, vol. 46, no. 7, p. 1007.

3. Meng L, Liu Y. H, Tian L. // J. Cryst. Growth, 2003, vol. 253, no. 1-4, p. 530 .

4. Миличко В. А., Шалин А. С. и др. // Усnехи физ. наук (обзоры актуальных проблем), 2016, т. 186, № 8, c. 801 .

5. Ellmer K. Hopfner C. // Philosophical Magazine A, 1997, vol. 75:4, p. 1129.

6. Ennaoui A., Fiechter S., Pettenkofer Ch., et al. // Solar Energy Materials and Solar Cells, 1993, vol. 29, p. 289.

7. Kruse O. // American Mineralogist, 1990, vol. 75, p. 755 .

8. Gronvold F., Stolen S. // J. Chem. Thermodyn., 1992, vol. 24, p. 913.

9. Диаграммы состояния двойных и многокомпонентных систем на основе железа / Под ред. О. А. Банных, М. Е. Дрица. М.: Металлургия, 1986, 440 с.

10. Hyde B., O'Keffee M. Marcasite, et al. // Aust. J. Chem, 1996, vol. 49, p. 867.

11. Bryndzia L. T., Scott S. D., Spry P. G. // Econ Geol, 1988, vol. 83, p. 1193.

12. Bennett C. E. G., Graham J., Thornber M. R. // Am Mineral, 1972, vol. 57, p. 445.

13. Прокин А. Н. Некоторые вопросы физикохимии синтетического и природного дисульфида железа. Дисс. ... канд. хим. наук. Воронеж, 1980, 225 с.

14. Minerals: Their Constitution and Origin / Ed. by H.-R. Wenk, A. Bulakh. Edinburgh Building, Cambridge, 2004, 647 p.

15. Nielsen H. P., Frandsen F. J. // Progress in Energy and Combustion Science, 2000, vol. 26, iss. 3, p. 283.

16. Тронина Е. М. и др. // Вестн. ЛГУ. Сер. физ. и хим., 1969, № 10, вып. 2, с. 83.

17. Fleet M. E. // Acta Crystallographica B, 1971, vol. 27, p. 1864.

18. Лидин Р. А., Андреева Л. Л., Молочко В. А. Справочник по неорганической химии. М.: Химия, 1987, $320 \mathrm{c}$.

19. Завражнов А. Ю., Наумов А. В. // Неорг. материальь, 2006, т. 42, № 12, с. 1420. 


\title{
THE PRECIPITATION OF IRON SULPHIDES BY THE CRYSTALLIZATION OF HALIDE MELTS IN SULPHUR ATMOSPHERE
}

\author{
(C) 2017 S. S. Berezin ${ }^{1}$, A. Yu. Zavrazhnov ${ }^{1}$, A. V. Naumov' ${ }^{1}$ V. V. Volkov ${ }^{2}$, \\ A. V. Sergeeva ${ }^{3}$, A. P. Spesivtsva ${ }^{1}$ \\ ${ }^{1}$ Voronezh State University, Universitetskaya sq., 1, 394018 Voronezh, Russia
}

\begin{abstract}
${ }^{2}$ Kurnakov Institute of General and Inorganic Chemistry of RAS, Leninsky pr., 31, 119991 Moscow, Russia ${ }^{3}$ Institute of Volcanology and Seismology, Far East Branch, Russian Academy of Sciences, blvd. Piypa, 9 , Petropavlovsk-Kamchatski, 983006 Russia e-mail:alzavr08@rambler.ru
\end{abstract}

Received 28.12.2016

\begin{abstract}
A new approach to a single crystals growth of the iron sulphide phases of definite structure and nonstoichiometry is developed and applied. This approach is based on the iron sulphides recrystallization from the solutions of these sulphides in the iron (II) halide melts at the fixed vapor pressure of sulphur. The recrystallization procedure is carried out in a closed non-isothermal system: the charge - the weight of iron sulphide and the solvent - the weight of iron (II) halide are located in the "hot" end of the silica ampoule at the temperature $T_{2}$ and the source of sulphur (pure $\mathrm{S}$ ) is concentrated in the opposite "cold" end of ampoule. The vapor pressure of sulphur is controlled by the temperature of the "cold" zone $\left(T_{1}\right)$. In the course of each grown experiment the temperature $T_{1}$ was unvaried (so the pressure of sulphur was unvaried too) and the temperature of the "hot" zone $T_{2}$ was decreased slowly (usually from 690 to $660{ }^{\circ} \mathrm{C}$ ). Pyrite single crystals was grown using the chloride and the bromide melts as the solvents when the vapor pressure of sulphur vapor was in the range from 0.42 to 9.4 bar. The lattice constant " $a$ " was equal to $0.5412-0.5413 \mathrm{~nm}$. The mixture of pyrite $\left(\beta-\mathrm{FeS}_{2}\right)$ and trigonal phase of $\mathrm{Fe}_{1-x} \mathrm{~S}$ was detected when the vapor pressure of sulphur was smaller than 0.25 bar. In the experiments with the iodide melts the almost complete oxidation of ion $\mathrm{I}^{-}$(to $\mathrm{I}_{2}$ ) by sulphur and the crystallization of iron sulphides were found. This paper proposes a mechanism for the generation of the iron sulphide phases from the iron halide melts.
\end{abstract}

Keywords: iron sulphides, pyrite, pyrrhotite, iron halide, recrystallization.

\section{ACKNOWLEDGEMENTS}

This work was supported by the Russian Foundation for Basic Research (project no. 15-52-61017 Egipet_a).

\section{REFERENCES}

1. Developments in Economic Geology, 30 Precambrian Ore Deposits of the East European \& Siberian Cratons / Ed. by D. V. Rundquist, C. Gillen. Elsevier, 1997, 457 p.

2. Wozniakiewicz P. J., Ishii H. A. Meteoritics \& Planetary Science, 2011, vol. 46, no. 7. P. 1007. DOI: 10.1111/j.1945-5100.2011.01206

3. Meng L, Liu Y. H, Tian L. J. Cryst. Growth, 2003, vol. 253, no. 1-4, p. 530. DOI: 10.1016/S0022-0248(03) 01040-6

4. Milichko V. A., Shalin A. S. Advances in Physical Sciences (Physics-Uspekhi), 2016, vol. 186, no. 8, p. 801. DOI: 10.3367/UFNr.2016.02.037703. (in Russian)

5. Ellmer K. Hopfner C. Philosophical Magazine A, 1997, vol. 75:4, p. 1129. DOI: 10.1080/01418619708214015

6. Ennaoui A., Fiechter S., Pettenkofer Ch., et al. Solar Energy Materials and Solar Cells, 1993, vol. 29, p. 289. DOI: 10.1016/0927-0248(93)90095-K
7. Kruse O. American Mineralogist, 1990, vol. 75, p. 755 .

8. Gronvold F., Stolen S. J. Chem. Thermodyn., 1992, vol. 24 , p. 913.

9. Diagrams of Binary and Multicomponent Systems Based on Iron / Ed. by O. A. Bannykh, M. E. Drits. Moscow, Metallurgiya Publ., 1986, 440 p. (in Russian)

10. Hyde B., O’Keffee M., et al. Aust. J. Chem, 1996, vol. 49, p. 867. DOI: 10.1071/CH9960867

11. Bryndzia L. T., Scott S. D., Spry P. G. Econ Geol, 1988, vol. 83, p. 1193.

12. Bennett C. E. G., Graham J., Thornber M. R. Am Mineral, 1972, vol. 57, p. 445.

13. Prokin A. N. Some Questions of Physical Chemistry of Synthetic and Natural Iron Disulfide. Diss. ... cand. chem. sci. Voronezh, 1980, 225 p. (in Russian)

14. Minerals: Their Constitution and Origin. Ed. by H.-R. Wenk, A. Bulakh. Edinburgh Building, Cambridge, 2004, 647 p.

15. Nielsen H. P., Frandsen F. J. Progress in Energy and Combustion Science, 2000, vol. 26, iss. 3, p. 283. 
16. Tronina E. M., et al. Vestnik of Pushkin Leningrad State University. Series. Physical. and Chemical, 1969, no. 10, p. 83. (in Russian)

17. Fleet M. E. Acta Crystallographica B, 1971, vol. 27, p. 1864.
18. Lidin R. A., Andreyeva L. L., Molochko V. A. Handbook of Inorganic Chemistry. Moscow, Chimiya Publ., 1987, 320 p. (in Russian)

19. Zavrazhnov A. Yu., Naumov A. V., Anorov P. V., et al. Inorganic Materials, 2006, vol. 42, no. 12, p. 1294. DOI: $10.1134 / \mathrm{S} 0020168506120028$
Березин Сергей Сергеевич - ассистент кафедры общей и неорганической химии, Воронежский государственный университет; e-mail: bss-15.11.88@mail.ru

Завражнов Александр Юрьевич - д. х. н., профессор кафедры общей и неорганической химии, Воронежский государственный университет; e-mail: alzavr08@rambler.ru

Наумов Александр Владимирович - к. х. н., н. с. кафедры общей и неорганической химии, Воронежский государственный университет; e-mail: aither@bk.ru

Волков Вячеслав Владимирович - к. х. Н., в. н. с., Институт общей и неорганической химии им. Н.С. Курнакова; e-mail: svolkov77@gmail.com

Сергеева Анастасия Валерьевна - к. х. н., с. н. с., Институт вулканологии и сейсмологии ДВО РАН, Петропавловск-Камчатский; e-mail: valraf2009@yandex.ru

Спесивиева Александра Павловна - студентка 4 курса, Воронежский государственный университет; e-mail: bss-15.11.88@mail.ru
Berezin Sergey S. - Lecturer, Department of General and Inorganic Chemistry, Voronezh State University; e-mail: bss-15.11.88@mail.ru

Zavrazhnov Alexander Y. - Dr. Sci. (Chem.), Department of General and Inorganic Chemistry, Voronezh State University; e-mail: alzavr08@rambler.ru

Naumov Alexander V. - Cand. Sci. (Chem.), Researcher, Department of General and Inorganic Chemistry; e-mail: aither@bk.ru.

Volkov Vyacheslav V. - Cand. Sci. (Chem.), Leading Researcher, Institute of General and Inorganic Chemistry; e-mail: svolkov77@gmail.com

Sergeeva Anastasiya V. - Cand. Sci. (Chem.), Senior Researcher, Institute of Volcanology and Seismology, Far East Branch, Russian Academy of Sciences, PetropavlovskKamchatski; e-mail: valraf2009@yandex.ru

Spesivtseva Alexandra P. - 4-y. student, Department of General and Inorganic Chemistry; e-mail: bss-15.11.88@ mail.ru 